\title{
Anti-oxidant Effects of Scutellarin in UVA-irradiated HaCaT Cells
}

Se-Eun Jeon ${ }^{1}$, Soo-Yeon Kim² ${ }^{2}$ Na-Kyeong Lee ${ }^{3}$, Seunghee Bae ${ }^{4}$, Jae-Nam Lee ${ }^{5 *}$

${ }^{1}$ Department of Biological Engineering, Konkuk University, Seoul, Korea

${ }^{2}$ Department of Beauty Art, Doowon Technical University, Paju-si, Gyeonggi-do, Korea

${ }^{3}$ Department of Cosmetics, JEI University, Incheon, Korea

${ }^{4}$ Research Institute for Molecular-Targeted Drugs, Department of Cosmetics Engineering, Konkuk University, Seoul, Korea,

${ }^{5}$ Department of Cosmetology, Graduate School of Engineering, Konkuk University, Seoul, Korea

*Corresponding author: Jae-Nam Lee, Department of Cosmetology, Graduate School of Engineering, Konkuk University, 120 Neungdongro, Gwangjin-gu, Seoul 05029, Korea

Tel.: +82 24503596

Email: jn386@konkuk.ac.kr

Received August 30, 2017

Revised September 28, 2017

Accepted September 29, 2017

Published December 30, 2017

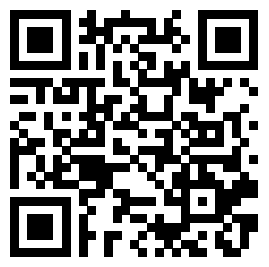

\begin{abstract}
Purpose: This study was to investigate the anti-oxidant activity of scutellarin in ultraviolet A (UVA)-irradiated HaCaT cells. Methods: To confirm the anti-oxidant effects of scutellarin, water-soluble tetrazolium salt (WST-1) was used to determine the cytotoxicity, 2', $7^{\prime}$-dichlorofluorescin diacetate (DCFDA) was used to quantitatively analyze intracellular reactive oxygen species (ROS), and quantitative real-time polymerase chain reaction ( $\mathrm{QRT}$-PCR) was used to determine the regulation of superoxide dismutase 1 (SOD1), catalase (CAT) and glutathione peroxidase 1 (GPX1) mRNA expression. Results: As a result, scutellarin had no toxicity, and effectively protected HaCaT cells from UVA in a concentration dependent manner. The intracellular ROS was increased by 2.15 times after cell irradiated with UVA, but decreased by 1.61-1.20 times in scutellarin pretreatment group. The expression of SOD1, CAT and GPX1 mRNA, which was downgraded by UVA irradiation, was upregulated in a concentration dependent manner in the scutellarin pretreatment group. Conclusion: This study confirmed that scutellarin regulated anti-oxidant defense mechanisms in HaCaT cells. Future research will be needed to confirm the application of scutellarin as a material for the development of functional cosmetics.
\end{abstract}

Keywords: Scutellarin, Human keratinocyte, Ultraviolet A, Anti-oxidant, Reactive oxygen species

\section{Introduction}

최근 의료과학의 발전, 경제성장, 생활수준의 향상으로 인 간의 평균수명이 연장되어 노령화 추세가 가속화되고 있다. 이에 인간의 항노화에 관한 관심이 더욱 증가되고 있으며, 특 히 피부의 형태학적 변화는 직접 눈으로 관찰할 수 있어 피부 노화 예방에 많은 관심이 집중되고 있다. 피부노화는 내인성 인자뿐만 아니라 외인성 인자에 의존하는 복합적인 과정이며 (Wohlrab, 2016), 외적 노화는 주로 자외선으로 인한 광노화 에 의해 발생되며 내적 노화를 촉진시킨다. 태양광선은 인간 의 세포내외에서 활성 산소종(ROS)을 생성시키므로 피부 노 화는 주로 자외선 노출과 관련된다. 피부는 광노화로 인하여 깊은 주름과 잔주름 생성, 과색소 침착, 피부건조 및 가려움, 탄력 감소 및 염증발생 등의 변화가 나타난다(Ahn, 2017;
Han et al., 2016).

자외선의 영역은 크게 단파장인 UVC $(200-280 \mathrm{~nm})$, 중파 장인 UVB (280-320 nm) 및 장파장인 UVA (320-400 nm) 로 구분된다. 에너지가 강하여 피부암 유발이 높은 UVC는 오존층에서 차단되므로 피부에 직접적인 영향을 미치는 자 외선은 UVB와 UVA이다. 그 중 UVA는 $95 \%$ 정도를 차지하 며 에너지는 상대적으로 약하지만 지속적으로 노출되면 다 양한 조직에서의 피부 손상을 일으킨다. 일상 자외선이라 불 리는 UVA는 자외선의 가장 보편적인 요소로써 세포나 피부 에 산화 스트레스 손상을 주며, 피부 깊숙이 침투하여 피부 결합 조직의 심각한 변화를 유도한다. UVA의 유해한 영향은 세포 수준에서 입증되었고 세포 기능과 조직 손상의 연쇄적 인 손상을 초래했으며(Battie et al., 2014; Ikehata \& Ono, 2011; Kripke, 1991) 그 외 피부에 미치는 수많은 생물학적 
영향을 갖는다. UVA는 인간각질형성세포의 세포 독성과 콜 라겐 분해를 통해 조기 피부 노화와 관련한 발병기전에서 중 요한 역할을 하며, 이를 통해 유발된 산화적 스트레스는 콜라 겐 손상을 야기하는 metalloprotease-1의 유도를 매개한다 (Pluemsamran et al., 2012). 결과적으로 자외선은 피부암 뿐만 아니라 활성산소에 기인한 조기 피부 노화를 발생시킨다 (Kammeyer \& Luiten, 2015; Shah \& He, 2015).

$\mathrm{McCord}$ 는 정상적인 호흡 시에 25 개의 산소분자가 환원될 때마다 1개의 프리라디칼(free radical)이 생성된다고 보고하 였다(McCord \& Fridovich, 1969). 생체내에서 항산화 물질 과 항산화 효소가 균형을 이루게 되면 활성산소를 제거하여 정상적인 대사작용을 가지게 된다. 그러나 필수불가결하게 신 체 내에서 발생되는 활성산소가 항산화시스템 불균형으로 신 체 내에서 제때에 제거되지 못하면 산화적 손상을 일으켜 각 종 질병과 피부노화의 원인이 된다(Blois, 1958; Kappus, 1986).

피부는 크게 바깥으로부터 표피층, 진피층, 피하조직으로 구성되어 있으며 주요 기능은 자외선, 외부 환경오염 물질 및 미생물 등의 침입을 방지하고 수분손실을 막는 피부 보호장벽 의 역할을 한다(Feingold \& Elias, 2014). 피부 노화는 기능 적, 구조적으로 변화되어 탄력 저하, 기미 및 주근깨 침착, 유 분 저하, 수분 손실 증가, 각질세포 응집력 강화, 주름 증가 등으로 나타난다(Freedberg, 1999).

Scutellarin은 황금, 골무 등에 포함된 성분으로 페놀화합 물의 일종인 flavone에 속한다. 동양에서는 한약재로도 쓰 이며 효능에 관한 연구들이 각 분야별로 진행되어 왔다. 플 라보노이드(flavonoid)의 일종인 scutellarin은 효율적인 항 산화제로 알려져 있으며(Liu et al., 2002), 산화적 스트레 스를 줄여주고 세포 사멸을 조절함으로써 $\mathrm{PC} 12$ 세포보호, 치매 쥐의 손상된 학습 능력과 기억력의 회복, 심근 세포에 서 허혈, 재관류 손상을 예방한다(Guo et al., 2011; Hong \& Liu , 2007; Wang et al., 2016)고 보고되었다. 하지만 scutellarin이 UVA 조사에 의해 산화적 스트레스가 유발된 인간각질형성세포에서 산화적 스트레스를 경감시키는 효능 이 있는지에 대한 연구는 아직 미미한 실정이다. 본 연구에서 는 scutellarin의 항산화 연구와 관련하여 각질형성세포에서 $S O D 1, C A T$ 및 GPX1 mRNA 발현 조절에 미치는 영향을 확 인해 보고, UVA 조사에 의해 증가된 활성산소가 scutellarin 에 의해 억제되어 보호되는지 확인하고자 한다. 결과적으로 scutellarin이 인간각질형성세포에서 UVA에 의해 유도된 산 화적 스트레스를 경감시켜 항산화 시스템을 보호하는지 입증 하고, 이를 통해 scutellarin의 항노화 화장품 소재로서의 가 능성을 알아보고자 한다.

\section{Methods}

\section{1. 세포배양 및 시료처리}

본 실험에는 인간각질형성세포주인 HaCaT cell (American Type Culture Collection, USA)이 사용되었다. 세포배양은 $10 \%$ fetal bovine serum (FBS; Hyclone ${ }^{\mathrm{TM}}$, GE Healthcare Life Sciences, USA)과 $1 \%$ penicillin/streptomycin (Hyclone ${ }^{\mathrm{TM}}$ ) 이 첨가된 Dulbecco's Modified Eagle Medium (DMEM; Hyclone ${ }^{\mathrm{TM}}$ )배지를 사용하여 $37^{\circ} \mathrm{C}, 5 \% \mathrm{CO}_{2}$ 세포배양기 조건에서 배양되었다. Scutellarin (Sigma-Aldrich, USA)은 분말타입으 로 구매하였고 실험에 사용할 때는 dimethyl sulfoxide (DMSO; Sigma-Aldrich)에 적정 농도별로 용해하여 사용하였고, UVA는 UV-A lamp (UVP, USA)를 이용하여 $10 \mathrm{~J} / \mathrm{cm}^{2}$ 의 강도로 조사 하였다.

\section{2. 세포생존율 측정}

Scutellarin의 세포독성 실험은 EZ-cytox Cell Viability Assay Kit (Itsbio, Korea)을 사용하였다. 세포생존율은 세 포 내 소기관인 미토콘드리아의 탈수소효소에 의해 생성되는 formazan의 흡광도를 측정하는 원리인 WST-1 assay을 이 용하였다. 인간각질형성세포 $\left(3 \times 10^{3}\right.$ cells/well)를 96-well plate에 $100 \mu \mathrm{L}$ 씩 분주한 후 $24 \mathrm{~h}$ 배양 후 scutellarin과 UVA 를 적정 농도 처리하고 $24 \mathrm{~h}$ 배양하였다. 배양된 세포에 EZcytox Cell Viability Assay Kit reagent $10 \mu \mathrm{L}$ 를 첨가하여 1 $\mathrm{h}$ 배양 후 $\mathrm{iMakr}^{\mathrm{TM}}$ microplate absorbance reader (Bio-Rad Laboratories, USA)를 이용하여 $450 \mathrm{~nm}$ 에서 흡광도를 측정 하였으며, 실험은 3 회 반복 수행하여 세포생존율 평균값을 도 출하였다.

\section{3. $\mathrm{mRNA}$ 추출과 $\mathrm{cDNA}$ 합성}

배양된 세포로부터의 mRNA 추출은 Trizol reagent (Invitrogen $^{\mathrm{TM}}$, Thermo Fisher Scientific, USA)를 이용 하여 mRNA를 추출하였으며, 추출된 mRNA는 Nanodrop (Maestrogen, USA)을 이용하여 순도를 측정하여 260/280 $\mathrm{nm}$ 의 ratio 1.8 이상의 mRNA만을 실험에 사용하였다. $\mathrm{cDNA}$ 는 $1 \mu \mathrm{g}$ RNA를 대상으로 Moloney Murine Leukemia Virus reverse transcriptase (M-MLV RT; Enzynomics, Korea)을 이용하여 합성하였다.

\section{4. $\mathrm{qRT}-\mathrm{PCR}$ 측정}

UVA와 scutellarin에 의해 인간각질형성세포내에서 일 어나는 $S O D 1, C A T, G P x 1$ 유전자 발현패턴을 정량적으로 분석하기 위하여 SYBR green (Invitrogen ${ }^{\mathrm{TM}}$ )을 이용하였 으며, Line-Gene K real-time PCR detection system 

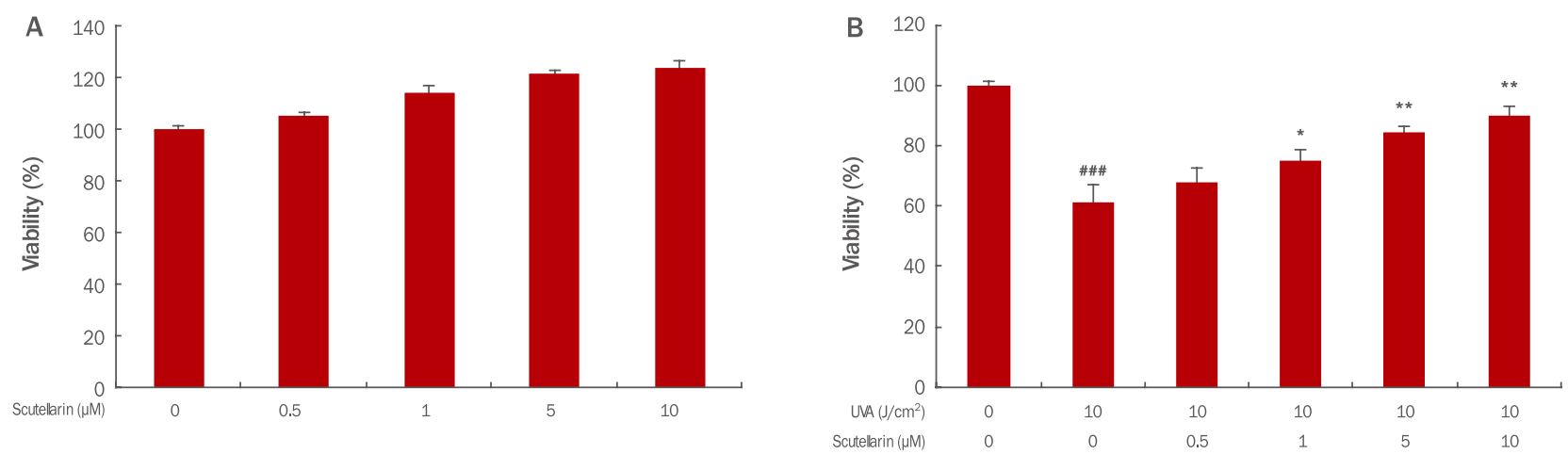

Figure 1. Cell viability of scutellarin in HaCaT cells and in UVA-irradiated HaCaT cells.

$\mathrm{HaCaT}$ cells $\left(3 \times 10^{3}\right)$ were seeded on 96-well plate and then incubated for $24 \mathrm{~h}$. Then, the cells were treated with $0.5,1,5$, and $10 \mu \mathrm{M}$ of scutellarin in each well. After additional incubation, cell viability of scutellarin in HaCaT cells (A) and in UVA-irradiated $\mathrm{HaCaT}$ cells (B) was measured by the WST-1 assay respectively. The graph represents the M \pm S.D. of the relative cell viability in each sample from triplicate experiments $\left({ }^{*} p<0.05,{ }^{* *} p<0.01\right.$ compared with UVA irradiated cells without scutellarin; ${ }^{\# \# \#<0.001}$ compared with negative controls that were not treated scutellarin and UVA irradiation). UVA, ultraviolet A; WST-1, water-soluble tetrazolium salt; $M \pm S$.D., mean \pm standard deviation.

(BioER, China)를 사용하여 PCR을 진행하였다. PCR 결 과의 유효성은 melting curve로 검증하였으며, 각 유전 자의 발현은 $\beta$-actin의 발현을 표준화하여 비교 분석 하 였다. 실험에 사용된 유전자의 primer는 Table 1과 같다.

\section{5. 세포내 ROS 변화량 측정}

세포 내 활성산소종 농도 변화를 측정하기 위하여 DCFDA (Sigma-Aldrich) assay를 사용하였다. 소수성 비 형광물질인 DCFDA가 세포막을 투과한 후 세포내 ROS 에 의해 산화되면 녹색의 형광을 띄는 $\mathrm{DCF}$ 로 변환된다 는 원리를 이용하여 측정하였다. 인간각질형성세포를 2 $\times 10^{5}$ cells/well로 분주하여 $24 \mathrm{~h}$ 배양 후 scutellarin 을 전처리한 후에 추가로 다시 배양하였다. 세포를 수확하 기 전에 $\mathrm{DCFDA}$ 를 $10 \mu \mathrm{M}$ 첨가하여 $30 \mathrm{~min}$ 배양 후 수 확한 세포를 $\mathrm{PBS}$ 로 세척하고 $1 \%$ trypsin-EDTA를 처리 하여 수확한 세포를 phosphate-buffered saline (PBS) 로 다시 세척하여 $\mathrm{BD}$ FACSCalibur ${ }^{\mathrm{TM}}$ flow cytometer (BD Biosciences, USA)를 이용하여 ROS량을 측정하였다 (excitation $\lambda$ : $485 \mathrm{~nm}$, emission $\lambda: 530 \mathrm{~nm}$ ). N-acetyl-
L-cystein (NAC; Calbiochem, USA)은 실험의 양성대조군 으로 동일한 과정을 거쳤다.

\section{6. 통계처리}

본 연구의 모든 실험은 동일한 조건하에 3 회 이상 반복 수 행하였다. 실험결과는 평균 \pm 표준 편차로 나타내었다. 실험 결과는 student' $t$-test로 검정하였고, 유의 수준은 0.05 이 하인 경우 통계적으로 유의하다고 분석하였다.

\section{Results and Discussion}

\section{Scutellarin의 UVA에 의한 세포독성 보호효과}

인간각질형성세포에서 scutellarin 자체의 세포 독성을 확인하기 위해서 인간각질형성세포에 scutellarin을 각각 $0,0.5,1,5 \mu \mathrm{M}$ 의 농도로 처리한 후, 세포생존율을 측정 하였다. 분석 결과, 모든 농도에서 세포독성이 나타나지 않 았다(Figure 1A). 한편 인간각질형성세포에서 UVA에 대 한 scutellarin의 세포보호효과를 확인하기 위하여 96-well

Table 1. List of primers used in this study

\begin{tabular}{lll}
\hline Gene & Forward primer $\left(5^{\prime} \rightarrow 3^{\prime}\right)$ & \\
SOD1 & GGGAGATGGCCCAACTACTG & Reverse primer $\left(5^{\prime} \rightarrow 3^{\prime}\right)$ \\
$G P \times 1$ & CCAGTTGACATGCAACCGTT \\
$C A T$ & TTCCGTGCAACCAGTTTG & GGACGTACTTGAGGGAATTCAGA \\
$\beta$-actin & GGATTCCATGCTCTCAAACC & CAGGTCATCCAATAGGAAGG \\
\hline
\end{tabular}

SOD1, superoxide dismutase 1; GPx1, Glutathione peroxidase 1; CAT, catalase; $\beta$-actin, actin beta. 


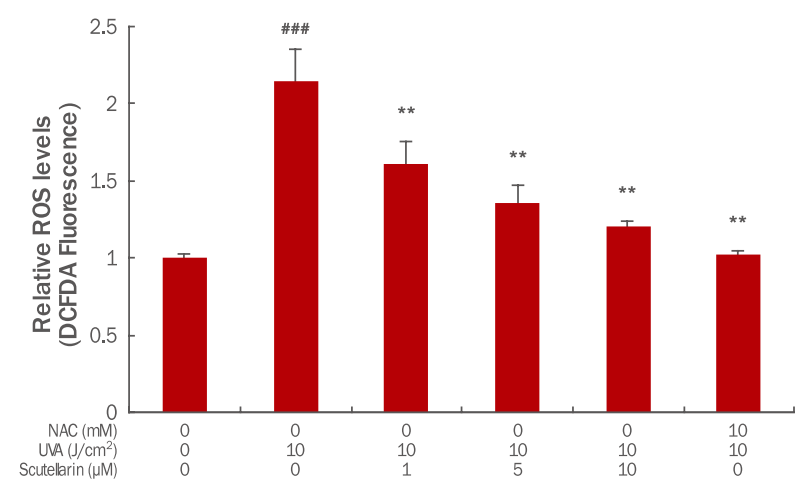

Figure 2. The ROS scavenging effects of scutellarin in UVAinduced $\mathrm{HaCaT}$ cells.

HaCaT $\left(2 \times 10^{5}\right)$ cells were seeded on $60 \mathrm{~mm}$ culture dish and then incubated for $24 \mathrm{~h}$. Prior to UVA, the cells were pretreated with 1, 5 and $10 \mu \mathrm{M}$ of scutellarin and $10 \mathrm{mM}$ NAC. Then, the cells were washed by PBS and irradiated by $10 \mathrm{~J} /$ $\mathrm{cm}^{2}$ UVA. After further incubation for $24 \mathrm{~h}$, the ROS level was measured by the flow cytometer. The graph represents the $M \pm S$.D. of the ROS level in each sample from triplicate experiments. The Student's $t$-test was conducted to determine statistical significance $\left({ }^{* *} p<0.01\right.$ compared with UVA irradiated cells without scutellarin and NAC; ${ }^{\# \#} p<0.001$ compared with negative controls that were not treated scutellarin, NAC and UVA irradiation). ROS, reactive oxygen species; DCFDA, 2',7'-dichlorofluorescin diacetate; NAC, N-acetyl-L-cystein; UVA, ultraviolet A; PBS, phosphate-buffered saline; $M \pm S . D$., mean \pm standard deviation.

plate에 인간각질형성세포를 $3 \times 10^{3}$ cells/well로 분주하여 $24 \mathrm{~h}$ 배양 후 scutellarin을 각각 $0,0.5,1,5,10 \mu \mathrm{M}$ 의 농 도로 $6 \mathrm{~h}$ 전처리하고, $\mathrm{UVA}$ 는 $10 \mathrm{~J} / \mathrm{cm}^{2}$ 의 강도로 조사하여 $24 \mathrm{~h}$ 배양하였다. 그 결과 세포생존율은 인간각질형성세포에 $\mathrm{UVA}$ 를 조사한 군에서 무처리군에 비해 $61 \%$ 의 세포생존율을 보였으나, scutellarin을 $0.5,1,5,10 \mu \mathrm{M}$ 전처리한 군에서 는 세포생존율은 각각 $75 \%, 84 \%, 90 \%$ 까지 농도 의존적으로 증가하여 높은 세포보호효과를 확인하였다(Figure 1B). 결과 적으로 인간각질형성세포에서 UVA에 의해 유도되는 세포독 성 및 세포 생장 저해에 scutellarin이 보호효과가 있음을 확 인하였다.

\section{2. 세포내 ROS 억제 효과}

Scutellarin이 UVA에 의해 세포내 발생하는 ROS의 억제 효능을 확인한 결과 인간각질형성세포에 $\mathrm{UVA}$ 를 $10 \mathrm{~J} / \mathrm{cm}^{2}$ 강 도로 조사하였을 때 UVA를 조사하지 않은 무처리대조군에 비해 ROS 생성량이 2.15배 증가하였으나 scutellarin을 1, 5, $10 \mu \mathrm{M}$ 전처리한 군에서의 $\mathrm{ROS}$ 는 각각 $1.61,1.36,1.20$ 배 로 농도 의존적으로 감소하였다. $10 \mathrm{~J} / \mathrm{cm}^{2}$ 강도로 UVA만 조 사하였을 때와 비교하여 scutellarin $10 \mu \mathrm{M}$ 전처리하였을 때
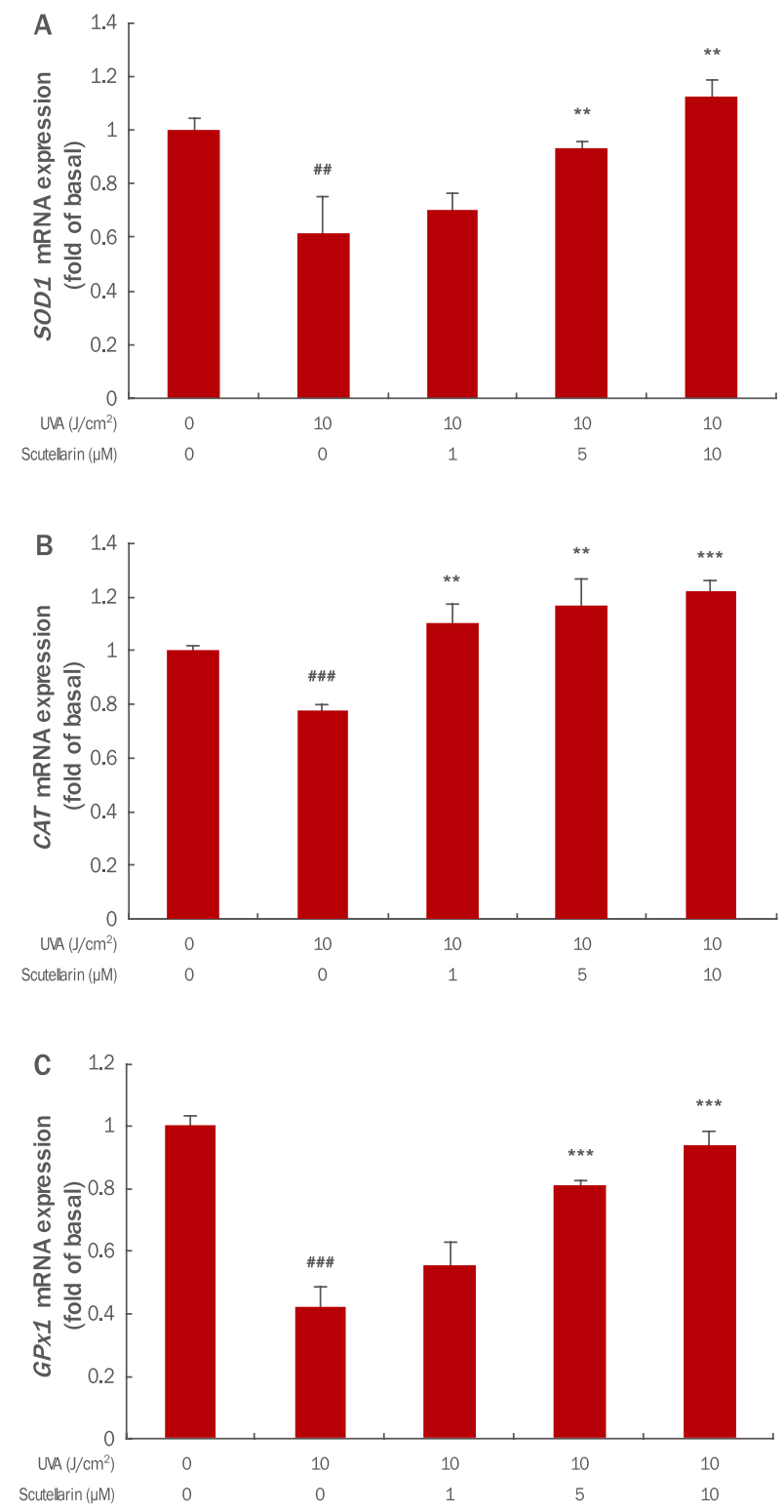

Figure 3. Effects of scutellarin on mRNA expression in UVAinduced HaCaT cells.

HaCaT $\left(2 \times 10^{5}\right)$ cells were seeded on $60 \mathrm{~mm}$ culture dish and incubated for $24 \mathrm{~h}$. Prior to UVA, the cells were pre-treated with 1,5 and $10 \mu \mathrm{M}$ of scutellarin. Then, the cells were washed by PBS and irradiated by $10 \mathrm{~J} / \mathrm{cm}^{2}$ UVA. After further incubation for $24 \mathrm{~h}$, the expression level of SOD1 (A), CAT (B), and $G P x 1(C)$ mRNA was measured by the qRT-PCR. The graph

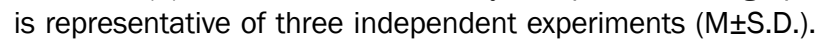
The Student's $t$-test was conducted to determine statistical significance $\left({ }^{* *} p<0.01,{ }^{* * *} p<0.001\right.$ compared with irradiated

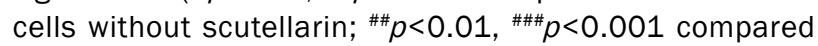
with negative controls that were not treated scutellarin and UVA irradiation). SOD1, superoxide dismutase 1; GPX1, glutathione peroxidase; $C A T$, catalase; UVA, ultraviolet A; qRT$\mathrm{PCR}$, quantitative real-time polymerase chain reaction; $\mathrm{M} \pm$ S.D., mean \pm standard deviation. 
$\mathrm{ROS}$ 억제 효능은 1.20 배 였고 양성대조군인 NAC $10 \mathrm{mM}$ 로 처리했을 때는 1.03 배로 확인되었다(Figure 2). 농도 대비 효 과로 비교해보면 ROS 소거제인 NAC에 비하여 scutellarin 이 더 효과적인 것을 확인할 수 있었다.

\section{SOD1, CAT 및 GPX1 mRNA expression 조절}

세포내 산화적 스트레스를 줄이는 대표적인 항산화 효소인 $\mathrm{SOD}$ 는 초과산화이온을 산소와 과산화수소로 바꿔 주는 불균 등화 반응을 촉매하는 효소이다. 산소에 노출되는 거의 모든 세포에서 항산화 방어기작을 하여 체내의 활성산소 농도를 낮 추는 역할을 한다(McCord \& Fridovich, 1969). SOD 효소군 은 크게 3 가지로 나누는데 그 중 하나인 SOD1은 주로 세포질 에 존재하며 산소가 존재하는 모든 조직에서 활성산소를 감 소시킨다(Crapo et al., 1992). Scutellarin의 항산화 기전을 확인하기 위하여 $S O D 1$ 의 인간각질형성세포내에서의 유전자 발현 변화 조절을 확인하기 위하여 $\mathrm{qRT}-\mathrm{PCR}$ 을 수행하였다. 그 결과 인간각질형성세포에 $\mathrm{UVA}$ 를 $10 \mathrm{~J} / \mathrm{cm}^{2}$ 강도로 조사 하였을 때 UVA를 조사하지 않은 무처리대조군에 비해 SOD1 mRNA 발현이 0.61배 하향되었으나, scutellarin을 $1,5,10$ $\mu \mathrm{M}$ 전처리한 군에서는 각각 $0.70,0.93,1.13$ 배로 상향 조 절되었다(Figure $3 \mathrm{~A}$ ). 그러므로 인간각질형성세포에서 UVA 조사로 인해 감소한 $S O D 1$ 유전자가 scutellarin 전처리를 통 해 농도 의존적으로 상향 조절됨으로써 활성산소에 의한 조직 손상을 보호하는 방어기전으로 역할을 한다.

$\mathrm{CAT}$ 는 거의 모든 호기성 세포의 peroxisome에 존재하며 안정된 효소로서 $\mathrm{H}_{2} \mathrm{O}_{2}$ 를 산소와 물로 분해함으로써 과산화 수소 증가에 따른 단백질, 핵산 및 생체막 등의 조직손상에 방어한다(Chance et al., 1979; Frank \& Massaro, 1980; Keilin \& Hartree, 1955). UVA에 의해 자극된 인간각질형성 세포에서 scutellarin의 CAT mRNA 발현 변화 조절을 확인 한 결과, $10 \mathrm{~J} / \mathrm{cm}^{2}$ 강도의 UVA조사에 의해 $C A T \mathrm{mRNA}$ 이 0.78 배 하향하였으나 scutellarin을 $1,5,10 \mu \mathrm{M}$ 전처리에 의 해 각각 $1.11,1.17,1.22$ 배로 상향 조절되었다(Figure 3B).

Glutathion peroxidase는 대부분 세포질에 존재하며 glutathion thiol (GSH)을 glutathione disulfide (GSSG)로 산화시킴과 동시에 $\mathrm{H}_{2} \mathrm{O}_{2}$ 를 $\mathrm{H}_{2} \mathrm{O}$ 로 환원시킨다. UVA에 의해 자극된 인간각질형성세포에서 scutellarin의 GPX1 mRNA 발현 변화를 확인한 결과, 인간각질형성세포에 UVA를 $10 \mathrm{~J} /$ $\mathrm{cm}^{2}$ 강도로 조사하였을 때 UVA를 조사하지 않은 무처리대 조군에 비해 0.42 배 하향하였으나 scutellarin을 $1,5,10 \mu$ $\mathrm{M}$ 전처리한 군에서의 $G P x 1 \mathrm{mRNA}$ 발현은 각각 $0.55,0.87$, 0.94배로 상향 조절되었다(Figure 3C).

\section{Conclusion}

본 연구에서는 scutellarin의 항산화 효능을 다양한 실험을 통해 확인하였다. Scutellarin은 $\mathrm{HaCaT}$ cell에서 그 자체로 세포독성이 나타나지 않았으며 UVA에 의한 세포손상을 농도의존적으로 회복 시키는 효과를 보여주었다. 더 나아가 UVA에 의해 유도된 세포내 $\mathrm{ROS}$ 를 농도 의존적으로 제거하는 효과를 확인하였다. 마지막으로 $\mathrm{UVA}$ 에 의해 감소한 항산화 효소인 $S O D 1, C A T$ 그리고 $G P \times 1$ 의 유 전자 발현을 농도 의존적으로 상향시켰다. 이러한 결과들을 종합해 볼 때 UVA 조사로 산화적 스트레스가 유발된 인간각질형성세포에 대해 scutellarin이 세포를 보호하고, 산화반응을 완화시키는 효과 가 있는 것으로 사료된다. 그동안 scutellarin은 항암, 항종양, 신경 세포 보호 그리고 항림프종과 같은 다양한 생물학적 활성이 보고되 었으나, 화장품 소재로서의 사용가능성은 보고가 미미하였다. 이에 scutellarin의 무독성, 세포보호 및 항산화 효과를 본 연구를 통해 확 인함으로써 향후 항산화 기능을 기반으로 한 anti-aging 화장품 소 재로서 활용가능 할 것으로 사료된다.

This work is part of the Seeun Jeon's Ph.D. thesis at the Konkuk University, Seoul, Korea..

\section{Acknowledgements}

본 논문은 보건복지부 보건의료연구개발사업의 지원(과제번호: $\mathrm{HN} 13 \mathrm{C0080)}$ )에 의한 것이며, 이에 감사드립니다.

\section{References}

Ahn KJ. Photoprotective effects of caffeic acid against ultraviolet-induced damages on human follicle dermal papilla cells. Asian Journal of Beauty and Cosmetology, 15: 105-111, 2017.

Battie C, Jitsukawa S, Bernerd F, Del Bino S, Marionnet C, Verschoore M. New insights in photoaging, UVA induced damage and skin types. Experimental Dermatology, 1: 7-12, 2014.

Blois MS. Antioxidant determinations by the use of a stable free radical. Nature, 181: 1199-1200, 1958.

Crapo JD, Oury T, Rabouille C, Slot JW, Chang LY. Copper,zinc superoxide dismutase is primarily a cytosolic protein in human cells. Proceedings of the National Academy of Sciences of the United States of America, 89: 1040510409, 1992.

Chance B, Sies H, Boveris A. Hydroperoxide metabolism in 
mammalian organs. Physiological Reviews, 59: 527605, 1979.

Feingold KR, Elias PM. Role of lipids in the formation and maintenance of the cutaneous permeability barrier. Biochimica et Biophysica Acta, 1841: 280-294, 2014.

Frank L, Massaro D. Oxygen toxicity. The American Journal of Medicine, 69: 117-126, 1980.

Freedberg IM, Fitzpatrick TB. Fitzpatrick's dermatology in general medicine (5th ed.). McGraw-Hill, New York, pp20-22, 1999.

Guo LL, Deng J, Wang YL, Huang Y, Guan ZZ. Influence of scutellarin on oxidative stress and neuronal apoptosis of rats with dementia. Journal of Chinese Medicinal Materials, 34: 237-241, 2011.

Han HS, Kim SY, Lim DJ, Whang WK. Development of whitening cosmetic ingredients from Cudrania tricuspidata stem extract. Asian Journal of Beauty and Cosmetology, 14: 317-328, 2016.

Hong H, Liu GQ. Scutellarin protects PC12 cells from oxidative stress-induced apoptosis. Journal of Asian Natural Products Research, 8: 471-479, 2006.

Ikehata $\mathrm{H}$, Ono T. The mechanisms of UV mutagenesis. Journal of Radiation Research, 52: 115-125, 2011.

Kammeyer A, Luiten RM. Oxidation events and skin aging. Ageing Research Reviews, 21: 16-29, 2015.

Kappus H. Overview of enzyme systems involved in bioreduction of drugs and in redox cycling. Biochemical Pharmacology, 35: 1-6, 1986.
Keilin D, Hartree EF. Catalase, peroxidase and metmyoglobin as catalysts of coupled peroxidatic reactions. Biochemical Journal, 60: 310-325, 1955.

Kripke ML. Immunological effects of ultraviolet radiation. The Journal of Dermatology, 18: 429-433, 1991.

Liu H, Yang X, Zhou L, Xu H. Study on effects of scutellarin on scavenging reactive oxygen. Journal of Chinese Medicinal Materials, 25: 491-493, 2002.

McCord JM, Fridovich I. Superoxide dismutase: an enzymic function for erythrocuprein (hemocuprein). The Journal of Biological Chemistry, 244: 6049-6055, 1969.

Pluemsamran T, Onkoksoong T, Panich U. Caffeic acid and ferulic acid inhibit UVA-induced matrix metalloproteinase -1 through regulation of antioxidant defense system in keratinocyte HaCaT cells. Photochemistry and Photobiology, 88: 961-968, 2012.

Shah P, He YY. Molecular regulation of UV-induced DNA repair. Photochemistry and Photobiology, 91: 254-264, 2015.

Wang Z, Yu J, Wu J, Qi F, Wang H, Wang Z, Xu Z. Scutellarin protects cardiomyocyte ischemia-reperfusion injury by reducing apoptosis and oxidative stress. Life Sciences, 157: 200-207, 2016.

Wohlrab J, Hilpert K, Wolff L. Epidermal aging and anti-aging strategies. Der Hautarzt, 67: 107-111, 2016. 


\section{국문초록}

\section{자외선 A에 의해 유도된 인간각질형성세포 손상에 대한 Scutellarin의 항산화 효과}

전세은 ${ }^{1}$, 김수연 ${ }^{2}$, 이나경 ${ }^{3}$, 배승희 ${ }^{4}$, 이재남 ${ }^{5 *}$

${ }^{1}$ 건국대학교 생물공학과, 서울, 한국

${ }^{2}$ 두원공과대학교 뷰티아트과, 경기도 파주시, 한국

${ }^{3}$ 인천재능대학교 화장품과, 인천, 한국

${ }^{4}$ 건국대학교 화장품공학과 질병분자표적신약연구소, 서울, 한국

${ }^{5}$ 건국대학교 산업대학원 향장학과, 서울, 한국

목적: 본 연구의 목적은 ultraviolet A (UVA)로부터 산화적 스트레스가 유도된 인간각질형성세포에서 scutellarin의 산화억제 효능 을 확인하는데 있다. 방법: Scutellarin의 항산화 효능을 확인하기 위하여 water-soluble tetrazolium salt (WST-1) assay를 이용한 세포독성 측정, $2,7^{\prime}$-dichlorofluorescin diacetate (DCFDA) assay를 통한 세포 내 활성산소종 정량분석 그리고 quantitative realtime polymerase chain reaction (qRT-PCR)을 통해 superoxide dismutase 1 (SOD1), catalase (CAT) 및 glutathione peroxidase $1(G P \times 1) \mathrm{mRNA}$ 의 발현 조절 양상을 측정하였다. 결과: Scutellarin는 그 자체로 독성을 보이지 않았고, 농도의존적으로 UVA로부 터 세포를 보호하는 효과가 있음이 확인되었다. UVA 조사에서는 세포 내 ROS가 2.15 배 증가하였으나 scutellarin 전처리 군에서는 1.61-1.20 배로 감소하였다. UVA 조사에 의해 저하된 SOD1, CAT 및 $G P x 1 \mathrm{mRNA}$ 의 발현은 scutellarin의 전처리 군에서 농도 의존적으로 증가 하였다. 결론: 본 연구결과를 통하여 scutellarin이 인간각질형성세포에서의 항산화 방어 메커니즘의 조절을 확인 하였고, 향후 scutellarin이 기능성 화장품 개발에 응용될 수 있는 소재로서의 활용을 확인하기 위하여 추가적인 기전 연구가 필요할 것으로 사료된다.

핵심어: Scutellarin, 인간각질형성세포, 자외선 A, 항산화, 활성산소

본 논문은 보건복지부 보건의료연구개발사업의 지원(과제번호: HN13C0080)에 의한 것이며, 이에 감사드립니다.

\section{참고문헌}

한효선, 김수연, 임대진, 황완균. 꾸지뽕나무 가지 추출물을 이용한 미백 기능성 화장품 소재 개발. 아시안뷰티화장품학술지, 14: 317-328, 2016.

안규중. 카페인산 처리를 통한 자외선B에 의해 유도된 세포 손상의 보호 효과 분석. 아시안뷰티화장품학술지, 15: 105-111, 2017. 


\title{
中文摘要
}

\section{Scutellarin对紫外线A诱导损伤的人皮肤角质形成细胞的抗氧化作用}

\author{
全世殷 ${ }^{1}$, 金秀妍 $^{2}$, 李奈耿 ${ }^{3}$, 裴承熙 ${ }^{4}$, 李在男 ${ }^{5 *}$ \\ 建国大学生物工学科, 首尔, 韩国 \\ ${ }^{2}$ 斗源工科大学美容艺术科, 京畿道坡州市, 韩国 \\ 仁川才能大学化妆品学科, 仁川, 韩国 \\ 建国大学化妆品工学科疾病分子靶标新药研究所, 首尔, 韩国 \\ 5建国大学产业大学院香妆学科, 首尔, 韩国
}

目的: 探讨scutellarin对ultraviolet A (UVA)诱导氧化应激的人皮肤角质形成细胞的抗氧化作用。方法: 为确定scutellarin的 抗氧化作用, 利用water-soluble tetrazolium salt (WST-1) assay测定scutellarin的细胞毒性, 利用2',7'-dichlorofluorescin diacetate (DCFDA) assay定量分析细胞内活性氧(reactive oxygen species, ROS)以及利用 quantitative real-time polymerase chain reaction（qRT-PCR）测定superoxide dismutase 1 (SOD1), catalase (CAT) 以及glutathione peroxidase 1 (GPX1) mRNA的表达量。结果: Scutellarin自身不具有毒性, 并且按浓度依赖性具有从UVA保护细胞的作 用。在UVA照射下, 细胞内增加了2.15倍ROS, 而在scutellarin预处理群中, 发现ROS降低1.61-1.20倍。在UVA照射下, $S O D 1, C A T$ 以及GPX1 mRNA的表达明显降低, 但在scutellarin预处理群中, 发现按浓度依赖性增加了其表达量。结论: 通过研究确认了scutellarin在人皮肤角质形成细胞内的抗氧化机制, 将来仍需进一步研究来确认scutellarin作为功能性化 妆品开发原料的应用。

关键词: Scutellarin，人皮肤角质形成细胞，紫外线A，抗氧化，活性氧 